\title{
A NEW SYRIAC INSCRIPTION IN DEIR AL-SURIAN (EGYPT)
}

\author{
LUCAS VAN ROMPAY \\ DUKE UNIVERSITY \\ DURHAM, USA \\ ANDREA B. SCHMIDT \\ UNIVERSITE CATHOLIQUE DE LOUVAIN \\ LOUVAIN-LA-NEUVE, BELGIUM
}

\begin{abstract}
This reports contains the edition and translation of a Syriac inscription recently discovered on an isolated beam of wood which was reused in a later door of the qasr of the Monastery of the Syrians. It mentions the names of the patriarchs of Antioch and Alexandria (Mor Ignatios and Mor Yubannon respectively) and is dated to the year 1597 of the Greeks, i.e., AD 1285/86. The original context of the inscription is not known.
\end{abstract}

[1] The keep or qasr of the Monastery of the Syrians is presently undergoing considerable reconstruction work which affects all the floors of this historic square building. During our stay in the Monastery in December 2000, Abouna Bulus El-Suriany, who is responsible for the work, was kind enough to give us some insight in the work and to inform us about its progress. On the third floor of the qasr, the northern side is occupied by the Church of St. 
Michael. Separated from it by a corridor, there is, on the eastern side, a room that served as a small library. While the qasr itself may date back to the ninth century, the Church of St. Michael is of a much later date. Evelyn White suggests the period around the year 1480, without however ruling out the possibility of a date as late as about 1700 [Evelyn White, III, 1933, 178].

A few months ago, a wooden door was removed from its place in the church and it turned out to contain a Syriac inscription. Abouna Bulus allowed us to take photographs of this inscription and, after consultation with Abouna Bigoul El-Souriany, His Grace Bishop Mattaos granted us permission to publish it.

The door is c. $182 \mathrm{~cm}$. in length and c. $107 \mathrm{~cm}$. in width. It is made up of pieces of different origin. One of these is a beam that now has the same length as the door $(182 \mathrm{~cm}$.). Originally, it must have been longer, as part of it had been cut or sawn off in order to allow it to be used in the new door. This beam seems to be much older than the rest of the door. A bit more than half of it $(97 \mathrm{~cm}$.) is covered with a Syriac inscription, of which the beginning is missing due to its having been trimmed. Although the text must have remained visible to the beholder, it may be safely assumed that the beam was reused without any attention being paid to the content of the Syriac inscription, which in this door is completely out of place.

The Syriac text, incised in the wood, is written in one line. The writing is a clearly, but somewhat clumsily written Estrangelo, which can be read easily [Fig. 1 shows the whole inscription, while Figs. 2, 3 , and 4 show in greater detail the first, central, and final parts respectively].

Text:

... Iy' d-dayro b-yawmay 'abohoto patryar(kee) Mor(y) Ignatyos w-Mo[ry] Yubannon ba-šnat nșz d-Yawnoyé.

\section{Translation:}

“... ] ... of the Monastery in the days of the Fathers Patriarchs Mor Ignatyos and Mor Yuhannon in the year 1597 of the Greeks.” 


\section{Notes:}

- The first letter, which must belong to the ending of a noun, might be either $y u d$ or nun.

- The word patryar(kè) is written in an abbreviated form, without the final kaf and 'olaf.

- The year is written as olaf-nun-sode-zayn, with a stroke above these four letters. Due to damage in the upper part of the nun, we have wondered whether perhaps sin ought to be read. This, however, seems unlikely.

The year 1597 "of the Greeks" corresponds to AD 1285/86. As is usual in Deir al-Surian, two patriarchs are mentioned: Ignatius (IV), patriarch of Antioch from 1283 to 1292 [Honigmann 1967, 73] and John (VII), who occupied the See of Alexandria between 1262 and 1268, and again between 1271 and 1293 [Labib 1991].

The preserved text must be the final part of an inscription which recorded building or other activities in the Monastery. It reminds one of the impressive Syriac inscriptions found on the lintel and the jambs of the doors closing the haikal and the khurus in the Church of the Virgin and dated to the years AD 914 and 926/7 respectively, when Moses of Nisibis was the abbot [Leroy 1974, 154-5; Van Rompay 1999, par. 30-3]. The new inscription is less elegant than the inscriptions from Moses' time and it is less carefully executed. It may originally have belonged to a lintel or jamb. Whether its original position was in the Church of the Virgin or elsewhere in the Monastery cannot be ascertained.

Very little is known of the history of the Monastery of the Syrians in the last decades of the thirteenth century. It has generally been assumed that the Church of the Virgin was redecorated around the year 1200 or somewhat later in the thirteenth century [Leroy 1982, 65-74; van Moorsel 1995, 519, with further references], but there is no evidence of building activities towards the end of the century. This was a period of hardship for the Christians in Egypt - as appears from the section on John IV in the History of the Patriarchs [Khater \& Burmester 1970, Arabic: 134; English: 229-30; compare Labib 1991]—and Evelyn White assumes that there was little literary and cultural activity in the Monastery [Evelyn White, II, 1932, 450].

On the other hand, there are indications that, possibly in the wake of the arrival of refugees from Syria about 1254, the number 
of monks was rather large [Evelyn White, II, 390-1]. In addition, we know of a few scribes working in the Monastery in that period. In 1280, Rabban Isa Saliba completed an Arabic manuscript in the Monastery [Bigoul El-Souriany, forthcoming]. One year later, in 1281, Solomon son of Simon wrote a Coptic manuscript [ibidem]. In 1291/2, a scribe from Tur 'Abdin, John of Hah, was working on two liturgical manuscripts: British Library, Add. 14,699 and Add. 14,700 [Wright, I, 1870, 305a and 306a]; the former manuscript is explicitly said to have been written for the Monastery.

Bringing these different pieces of information together, one can imagine that modest building or reconstruction activities were undertaken in order to meet the actual needs of the Monastery. Our new inscription may be the sober witness of such activities.

\section{BIBLIOGRAPHY}

Bigoul El-Souriany, forthcoming: Father Bigoul El-Souriany. "Manuscript Collection of Deir al-Surian: Its Survival into the Third Millennium." In Proceedings of the International Congress of Coptic Studies, Leiden 27 August - 2 September 2000.

Evelyn White, II, 1932: Evelyn White, Hugh G. The Monasteries of the Wâdi ' $n$ Natruin, Part II. The History of the Monasteries of Nitria and Scetis. New York, 1932; Reprint 1973.

Evelyn White, III, 1933: Evelyn White, Hugh G. The Monasteries of the Wâdi 'n Natrin, Part III. The Arcbitecture and Archaeology. New York, 1933; Reprint 1973.

Honigmann 1967: Honigmann, Ernest. Le couvent de Barsauma et le patriarcat jacobite d'Antioche et de Syrie. Corpus Scriptorum Christianorum Orientalium, 146; Subsidia, 7. Louvain, 1967.

Khater \& Burmester 1970: Khater, A., \& O.H.E. Khs-Burmester. History of the Patriarchs of the Egyptian Cburch, Vol. III, Part III. Cyril II Cyril V (A.D. 1235-1894). Publications de la Société d'archéologie copte. Textes et documents, XIII. Cairo, 1970.

Labib 1991: Labib, Subhi Y. "John VII.” In Aziz S. Atiya, ed. The Coptic Encyclopedia, vol. 4, 1342-3. New York, 1991.

Leroy 1974: Leroy, Jules. "Le décor de l'église du couvent des Syriens au Ouady Natroun." Cabiers archéologiques 23 (1974): 151-67.

Leroy 1982: Leroy, Jules. Les peintures des couvents du Ouady Natroun (= La peinture murale chez. les Coptes, II: Mémoires publiés par les membres de l'Institut français d'archéologie orientale du Caire, 101) Cairo, 1982.

Van Moorsel 1995: van Moorsel, Paul P.V. "La grande annonciation de Deir es-Sourian." Bulletin de l'Institut français d'archéologie orientale 95 
(1995): 517-37. Reprinted in van Moorsel, P.P.V. Called to Egypt. Collected Studies on Painting in Christian Egypt, 203-24 (no. 16). Publications of the 'De Goeje Fund', 30. Leiden, 2000.

Van Rompay 1999: Van Rompay, Lucas. "Syriac Inscriptions in Deir alSurian: Some Reflections on Their Writers and Readers." Hugoye 2/2 (July 1999).

\section{ILLUSTRATIONS:}

Fig. 1. Part of the wooden door, laying on the ground, with an overview of the Syriac inscription.

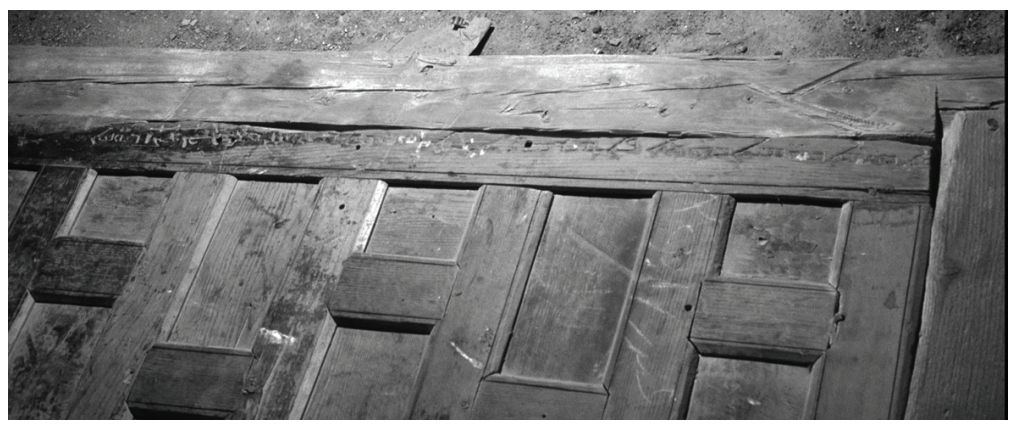

Fig. 2. Detail of the Syriac inscription: the first part.

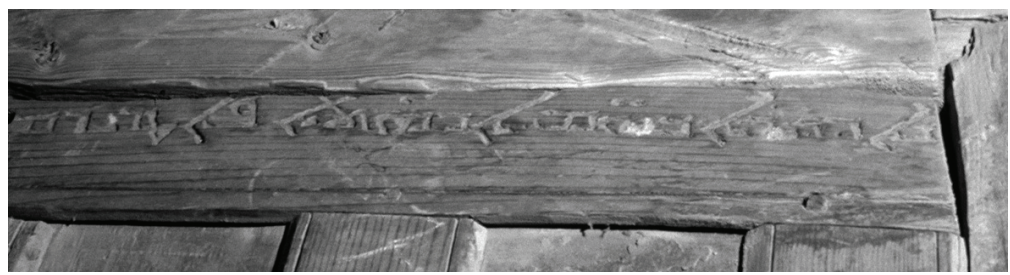

Fig. 3. Detail of the Syriac inscription: the central part.

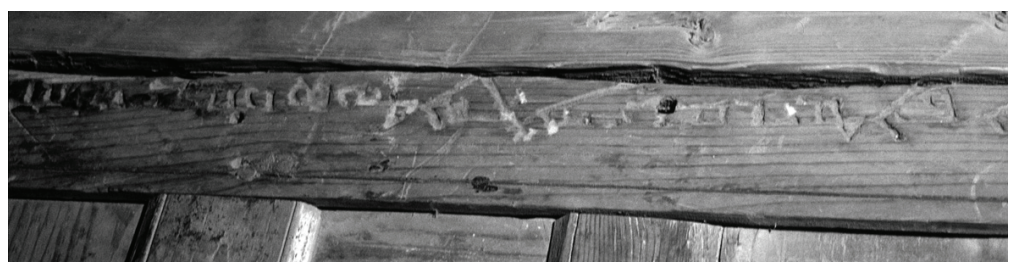


Fig. 4. Detail of the Syriac inscription: the final part, containing the date.

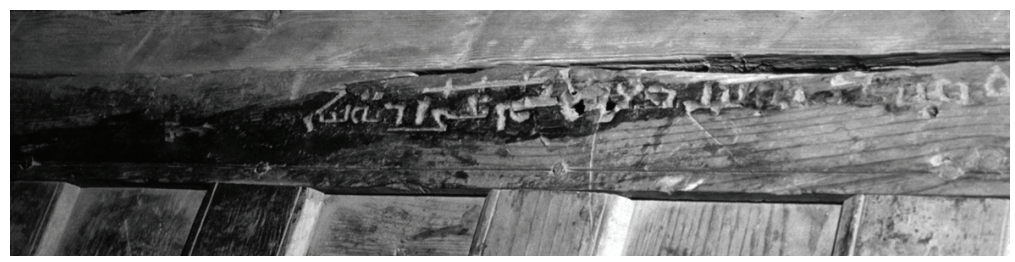

